\title{
Evaluation of Rice (Oryza sativa L.) Genotypes at Germination and Early Seedling Stage for Their Tolerance to Salinity
}

\author{
M.M. Islam* and M.A. Karim \\ Department of Agronomy, Bangabandhu Sheikh Mujibur Rahman Agricultural University \\ Gazipur-1706, Bangladesh \\ *Corresponding author and Email: hiraagron@yahoo.com
}

Received: 11 November 2010

Accepted: 17 March 2011

\begin{abstract}
An experiment was conducted at the Laboratory of Agronomy Department, Bangabandhu Sheikh Mujibur Rahman Agricultural University (BSMRAU), Gazipur from July-June, 2009-2010 to evaluate the rice (Oryza sativa L.) genotypes for their tolerance to salinity. One hundred rice genotypes and two check cultivars (Pokkali as tolerant and IR29 as susceptible) were exposed to solution of Electrical Conductivity (EC) of 10,15 , and $20 \mathrm{dSm}^{-1}\left(5: 1\right.$ molar concentration of $\mathrm{NaCl}$ and $\mathrm{CaCl}_{2}$ solution) at germination and early seedling stage. Based on visual salt injury symptoms at $15 \mathrm{dSm}^{-1}, 13$ genotypes were found fairly tolerant to salinity. However, among the 13 genotypes, only Patnai23 showed higher germination index and seedling relative dry weight than the check salt tolerant Pokkali at $15 \mathrm{dSm}^{-1}$. Beside these, performance of Awned-1, Nonasail and Soloi was also well at this level. The genotypes Patnai23, Awned-1, Nonasail and Soloi showed the best performance under saline condition.
\end{abstract}

Keywords: Rice genotypes, germination, salinity, tolerance

\section{Introduction}

Salinity results in poor plant stand due to decrease in the rate of seed germination and seedling survival for most of the agricultural crops (Karim et al., 1992). Rice is generally sensitive to salinity (Yeo et al., 1991) though rice varieties differ greatly in salt tolerance (Akbar et al., 1997; Amin et al., 1996; Yeo et al., 1991). Salinity may affect seed germination in two ways: (a) osmotically, by decreasing the ease with which seeds may take up water; and (b) ionically, by facilitating the uptake of ions in excess amount to be toxic for the embryonic activity (Ayers, 1953). For many plants, salt stress is more inhibitor during seed germination than at any other stage of growth (Bewley and Black, 1982). Seed germination is affected by the increase in salinity (Pushpam and Rangasamy, 2002). According to Yoshida (1981) rice is more sensitive to salinity during early seedling growth and flowering than other growth stages. Under saline conditions germination ability of seeds differs from one crop to another and even amongst the cultivars of the same crop (Asana and Kale, 1965; Maliwal and Paliwal, 1967; Kumar and Bhardwaj, 1981). Rice cultivars are also reported to show a great variation in germination due to salinity (Afroze, 1996). 
In Bangladesh, modern rice cultivars tolerant to saline soils are few in number. Works on salt tolerance of rice cultivars are generally scanty in Bangladesh (BRRI, 1995; Banik et al., 1994; Quayyum et al., 1991). Although several studies have been conducted for analyzing salt tolerance of rice at early growth stages (Islam et al., 2007; Akbar and Yabuno, 1975; Mondal et al., 1988; Reddy and Vaidyanath, 1982; Afroze, 1996) the information on comparative performance of different types of rice is quite low. The aim of the present investigation was to analyze genotypic variations in salt tolerance of rice at germination and early seedling stage of growth.

\section{Materials and Methods}

A laboratory experiment was conducted at the Department of Agronomy, Bangabandhu Sheikh Mujibur Rahman Agricultural University (BSMRAU), Gazipur, Bangladesh during July, 2009 to June, 2010. One hundred genotypes/landraces of rice (Oryza sativa L.) and two check cultivars Pokkali as tolerant and IR29 as susceptible were used in the experiment. Most of the genotypes were collected from Genetic Resources Unit of BSMRAU that includes land races and some HYV from Bangladesh, India and Thailand and rest of the genotypes were collect from the Bangladesh Rice Research Institute (BRRI).

Three levels of $\mathrm{NaCl}$ and $\mathrm{CaCl}_{2}$ (5:1 molar concentration) solution namely $10,15,20$ $\mathrm{dSm}^{-1}$ and distilled water as the control made up a total of four salinity treatments. Fifty seeds from each genotype in each treatment were placed for germination on filter paper in $10 \mathrm{~cm}$ diameter Petri dish. The Petri dishes were kept under laboratory conditions. After 3 days, when seedlings were well established, the distilled water was replaced with salinized solution. The number of germinated seeds were recorded at 24 hours interval for 9 days. Seeds were considered germinated when both plumule and radicle extended to more than 2 $\mathrm{mm}$ from the seeds. The experiment was laid out in a complete randomized design (CRD) with four replications. The modified standard evaluating scores were used for screening of the rice genotypes (Table 1). This scoring discriminates the susceptible from the tolerant and the moderately tolerant genotypes.

Table 1. Modified standard evaluation score (SES) of visual salt injury at seedling stage. (Gregorio et al. 1997)

\begin{tabular}{lll}
\hline \multicolumn{1}{c}{ Observation } & Tolerance & Score \\
\hline Normal growth, no leaf symptoms & Highly tolerant & 1 \\
$\begin{array}{l}\text { Nearly normal growth, but leaf tips or few leaves whitish and } \\
\text { rolled }\end{array}$ & Tolerant & 3 \\
$\begin{array}{l}\text { Growth severely retarded; most leaves rolled; only a few are } \\
\text { elongating }\end{array}$ & Moderately tolerant & 5 \\
$\begin{array}{l}\text { Complete cessation of growth; most leaves dry; some plants } \\
\text { dying }\end{array}$ & Susceptible & 7 \\
Almost all plants dead or dying. & Highly susceptible & 9 \\
\hline
\end{tabular}




\subsection{Germination Index}

The germination index was calculated after final germination following Karim et al. (1992) as:

$\left[\mathrm{GI}=\frac{\text { Germination } \mathrm{n} \text { percentage in each treatment }}{\text { Germination percentage in the control }} \times 100\right]$

\subsection{Seedling height and dry weight}

Seedling height was recorded on the $9^{\text {th }}$ day after the seeds were placed for germination. After harvest on the $9^{\text {th }}$ day, the seedlings were oven dried at $70^{\circ} \mathrm{C}$ until they reached a constant weight. Data on germination and seedling characteristics for each treatment were compared with control for determining the salt tolerant rice genotypes.

\subsection{Seedling height reduction}

The seedling height reduction (SHR) was calculated using the following equation:

$\left[\right.$ SHR $\left.(\%)=\frac{\text { Plant height at control }- \text { Plant height at saline condition }}{\text { Plant height at saline condition }} \times 100\right]$

\subsection{Relative dry weight}

The relative dry weight (RDW) was calculated using the following equation

$\left[\right.$ RDW $\left.(\%)=\frac{\text { Total dry weight under saline condition }}{\text { Total dry weight under control condition }} x 100\right]$

The data were analyzed statistically following CRD design by MSTAT-C computer package developed by Russel (1986). The mean separation was done by Duncan's Multiple Range Test (DMRT).

\section{Results and Discussion}

\subsection{Visual scoring of salt injury at seedling stage}

The modified standard evaluating score of salt injury method was used for screening the 100 rice genotypes and compared with the two check cultivars at seedling stage. It was found that 13 genotypes were tolerant and two genotypes were moderately tolerant at $15 \mathrm{dSm}^{-1}$ (Table2). However, all the selected genotypes were found moderately tolerant to $20 \mathrm{dSm}^{-1}$ except the two i.e. Tilkapur and Chinikamini2. For this reason, only genotypes tolerant to $15 \mathrm{dSm}^{-1}$ were considered for further discussion.

\subsection{Percent germination and germination index (GI)}

Effect of different salinity level had significant effect on percent seed germination of different rice varieties. The maximum percentage of germination was found in control condition and the minimum was in $20 \mathrm{dSm}^{-1}$ (Table 3). The results revealed that germination percent decreased with the increasing salinity levels. At $15 \mathrm{dSm}^{-1}$ salinity lever, the highest seed germination was found in Patnai23 (89.3\%). Salt concentration above $20 \mathrm{dSm}^{-1}$ drastically reduced germination and all the selected genotypes had germination less than $80 \%$. At this level Patnai23 showed the highest germination percentage (Table 3). Salinity decreased germination of seeds which is directly related to the amount of absorbed water by the seeds.

However, the GI of Patnai23, Awned-1, Gunshi, Soloi was found similar to that of the check Pokkali (Table 4). The results further indicated that these materials showed superiority over the rest selected genotypes in relation to germination at $15 \mathrm{dSm}^{-1}$. Hossain (2004) and Khan et al. (1997) also found that germination percentage and germination index of different rice genotypes were decreased with the increase in salinity levels. Similar results were also reported by Koyro and Eisa (2008) and Pushpam and Rangasamy (2002). 
Table 2. Visual score at seedling stage of different rice genotypes under varied salinity levels

\begin{tabular}{l|c|ccc}
\hline \multirow{2}{*}{ Genotypes } & \multicolumn{4}{c}{ Visual score } \\
\cline { 2 - 4 } & Control & \multicolumn{2}{c}{10} & 15 \\
\cline { 2 - 4 } Awned-1 & 1 & 1 & 3 & 20 \\
Kalguchi & 1 & 1 & 3 & 5 \\
Black & 1 & 1 & 3 & 5 \\
Chini atab & 1 & 1 & 3 & 5 \\
Til kapur & 1 & 3 & 5 & 7 \\
Chini kamini-2 & 1 & 3 & 5 & 7 \\
Rajbhog-2 & 1 & 1 & 3 & 5 \\
Khorina & 1 & 1 & 3 & 5 \\
Soloi & 1 & 3 & 3 & 5 \\
Nonasail & 1 & 1 & 3 & 5 \\
Patnai 23 & 1 & 3 & 3 & 5 \\
Sada mota & 1 & 1 & 3 & 5 \\
Gunshi & 1 & 1 & 3 & 5 \\
Koijuri & 1 & 1 & 3 & 5 \\
Chapali & 1 & 1 & 3 & 5 \\
IR-29 (check) & 1 & 5 & 7 & 3 \\
Pokkali (check) & 1 & 1 & 1 & 3 \\
\hline
\end{tabular}

Table3. Germination percentage of different rice genotypes under varied salinity levels

\begin{tabular}{|c|c|c|c|c|}
\hline \multirow{3}{*}{ Genotypes } & \multicolumn{4}{|c|}{ Germination (\%) } \\
\hline & \multirow{2}{*}{ Control } & 10 & \multirow{2}{*}{$\begin{array}{c}15 \\
\mathrm{dSm}^{-1}\end{array}$} & \multirow[t]{2}{*}{20} \\
\hline & & & & \\
\hline Awned-1 & 92.7 & $86.7 \mathrm{bc}$ & $83.3 \mathrm{bc}$ & $75.0 \mathrm{a}$ \\
\hline Hati sail (G-20) & 94.0 & 82.0 def & $77.3 \mathrm{def}$ & $69.7 \mathrm{bc}$ \\
\hline Black & 90.7 & $81.7 \mathrm{ef}$ & $77.0 \mathrm{ef}$ & $70.0 \mathrm{bc}$ \\
\hline Chini atab & 95.0 & $85.3 \mathrm{cdf}$ & $76.7 \mathrm{f}$ & $72.5 \mathrm{abc}$ \\
\hline Til kapur & 90.7 & $79.3 \mathrm{f}$ & $73.3 \mathrm{cdf}$ & $64.3 \mathrm{~d}$ \\
\hline Chini kamini-2 & 96.7 & $84.3 \mathrm{cdf}$ & 78.3 bcde & $68.3 \mathrm{~cd}$ \\
\hline Rajbhog-2 & 91.2 & $85.0 \mathrm{cdf}$ & 80.0 bcd & $69.7 \mathrm{bc}$ \\
\hline Khorina & 95.6 & $86.6 \mathrm{bc}$ & $81.8 \mathrm{bc}$ & $73.3 \mathrm{ab}$ \\
\hline Soloi & 92.5 & $84.3 \mathrm{cdf}$ & $82.1 \mathrm{bc}$ & $75.7 \mathrm{a}$ \\
\hline Nonasail & 97.3 & $89.7 \mathrm{ab}$ & $81.0 \mathrm{bc}$ & $75.7 \mathrm{a}$ \\
\hline Patnai 23 & 96.3 & $92.7 \mathrm{a}$ & $89.3 \mathrm{a}$ & $75.8 \mathrm{a}$ \\
\hline Sada mota & 93.1 & $86.0 \mathrm{bcd}$ & $82.0 \mathrm{bc}$ & $75.7 \mathrm{a}$ \\
\hline Gunshi & 88.3 & $82.0 \mathrm{def}$ & 79.0 cde & $72.7 \mathrm{abc}$ \\
\hline Koijuri & 90.2 & $83.0 \mathrm{cdef}$ & 78.7 cde & $73.7 \mathrm{ab}$ \\
\hline Chapali & 93.7 & $87.0 \mathrm{bc}$ & $82.3 \mathrm{bc}$ & $74.0 \mathrm{ab}$ \\
\hline IR-29 (check) & 95.6 & $81.3 \mathrm{ef}$ & $77.3 \mathrm{def}$ & $69.2 \mathrm{bc}$ \\
\hline Pokkali (check) & 93.4 & $88.2 \mathrm{~b}$ & $83.7 \mathrm{~b}$ & $74.5 \mathrm{a}$ \\
\hline $\mathrm{Sx}$ & 0.97 & 0.93 & 1.0 & 1.1 \\
\hline
\end{tabular}

Figure having common letter(s) in a column do not differ significantly at 5\% level of significance. 
Table 4. Germination index of different rice genotypes under varied salinity levels

\begin{tabular}{|c|c|c|c|c|}
\hline \multirow[b]{2}{*}{ Genotypes } & \multicolumn{4}{|c|}{ Germination Index } \\
\hline & Control & 10 & $\begin{array}{c}15 \\
-\mathrm{dSm}^{-1}\end{array}$ & 20 \\
\hline Awned-1 & - & 93.5 & 89.9 & 80.9 \\
\hline Hati sail (G-20) & - & 87.2 & 82.2 & 74.1 \\
\hline Black & - & 90.1 & 84.9 & 77.2 \\
\hline Chini atab & - & 89.8 & 80.7 & 76.3 \\
\hline Til kapur & - & 87.4 & 80.8 & 70.9 \\
\hline Chini kamini-2 & - & 87.2 & 81.0 & 70.6 \\
\hline Rajbhog-2 & - & 93.2 & 87.7 & 76.4 \\
\hline Khorina & - & 90.6 & 85.6 & 76.7 \\
\hline Soloi & - & 91.1 & 88.8 & 81.8 \\
\hline Nonasail & - & 92.2 & 83.2 & 77.8 \\
\hline Patnai 23 & - & 96.3 & 92.7 & 78.7 \\
\hline Sada mota & - & 92.4 & 88.1 & 81.3 \\
\hline Gunshi & - & 92.9 & 89.5 & 82.3 \\
\hline Koijuri & - & 92.0 & 87.3 & 81.7 \\
\hline Chapali & - & 92.8 & 87.8 & 79.0 \\
\hline IR-29 (check) & - & 85.0 & 80.9 & 72.4 \\
\hline Pokkali (check) & - & 94.4 & 89.6 & 79.8 \\
\hline
\end{tabular}

\subsection{Seedling height and its dry weight}

As in the case of germination percentage, seedling height also decreased with the increase in salinity level (Table 5). The highest reduction of seedling height was recorded at $20 \mathrm{dSm}^{-1}$ (Fig. 1). However, the difference in reduction percentage at 10 and $15 \mathrm{dSm}^{-1}$ was minimum; and for this reason salinity level of $15 \mathrm{dSm}^{-1}$ may be considered as the optimum for screening of rice genotypes. In contrary, the seedling height reduction percentage at $15 \mathrm{dSm}^{-1}$ was far less in Patnai23, Nonasail, Chapali, Awned-1 and Sadamota than the check tolerant Pokkali variety. The decrease of seedling height was due to the application of salinity which was also reported by early investigators (Zeng and Shannon, 2000).

The seedling dry weight and relative dry weight of different rice genotypes were influenced by salinity stress. In all genotype the seedling dry weight and percent relative dry weight were decreased due to increasing the salinity level (Tables 6 and 7). At $15 \mathrm{dSm}^{-1}$ salinity lever, the highest relative dry weight was found in Patnai23 $(90.88 \%)$ and the lowest $(70.1 \%)$ in IR29 (Table 7). Awned-1 (84.52\%), Nonasail (90.78\%), Soloi (83.28\%), also perform better compared to others variety (Table 7). The result indicated that as the salinity level increased, seedling dry weight and percent relative dry weight decreased. Islam et al. (2007) found that total chlorophyll content was reduced with increased levels of salinity. So, seedling dry weight decreased due to reduction of chlorophyll content under saline condition. Hossain (2004), Roy et al. (2002) and Khan et al. (1997) also found that seedling height and dry weight of different rice genotypes showed a declining trend with the increase of salinity level. 
Table 5. Seedling height of different rice genotypes under varied salinity levels

\begin{tabular}{|c|c|c|c|c|}
\hline \multirow{2}{*}{ Genotypes } & \multicolumn{4}{|c|}{ Seedling height $(\mathrm{cm})$} \\
\hline & Control & 10 & $\begin{array}{c}15 \\
\mathrm{dSm}^{-1}\end{array}$ & 20 \\
\hline Awned-1 & 13.93 & 13.24 & 12.26 & 11.3 \\
\hline Hati sail (G-20) & 14.22 & 12.7 & 12.24 & 10.8 \\
\hline Black & 16.35 & 14.68 & 13.84 & 11.5 \\
\hline Chini atab & 14.04 & 12.11 & 12.1 & 10.1 \\
\hline Til kapur & 11.53 & 10.05 & 9.81 & 9.0 \\
\hline Chini kamini-2 & 15.04 & 13.56 & 12.86 & 10 \\
\hline Rajbhog-2 & 13.01 & 11.26 & 11.26 & 9.5 \\
\hline Khorina & 16.34 & 15 & 13.7 & 10.5 \\
\hline Soloi & 14.53 & 12.96 & 13.32 & 10.88 \\
\hline Nonasail & 21.68 & 20.3 & 19.53 & 17.90 \\
\hline Patnai 23 & 22.29 & 20.46 & 20.15 & 17.90 \\
\hline Sada mota & 23.53 & 22.59 & 20.61 & 17.89 \\
\hline Gunshi & 25.57 & 22.07 & 20.63 & 18.27 \\
\hline Koijuri & 19.2 & 17.57 & 16.38 & 13.23 \\
\hline Chapali & 17.1 & 15.74 & 15.34 & 13.54 \\
\hline IR-29 (check) & 16.9 & 12.47 & 10.37 & 9.45 \\
\hline Pokkali (check) & 19.6 & 17.62 & 16.66 & 15.35 \\
\hline
\end{tabular}

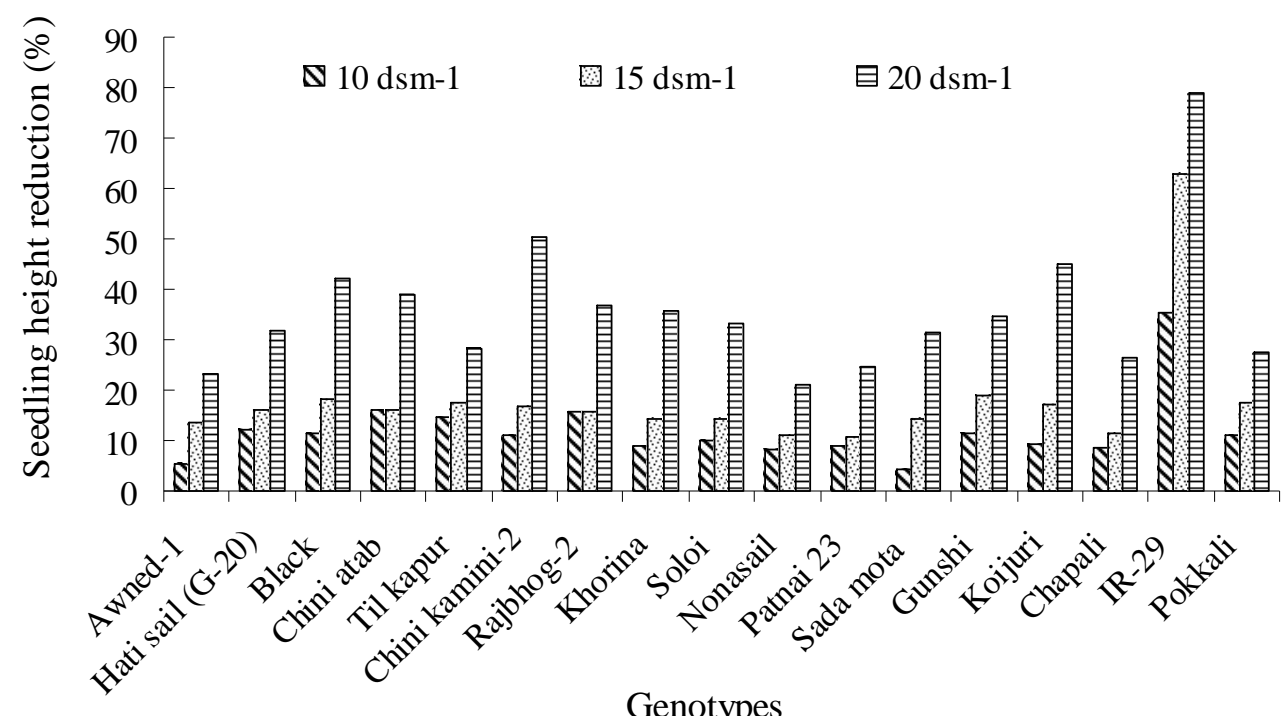

Fig. 1. Seedling height reduction (\%) of different rice genotypes under varied salinity level. 
Table 6. Seedling dry weight of different rice genotypes under varied salinity levels

\begin{tabular}{|c|c|c|c|c|}
\hline \multirow[b]{2}{*}{ Genotypes } & \multicolumn{4}{|c|}{ Seedling dry weight (mg) } \\
\hline & Control & 10 & 15 & 20 \\
\hline Awned-1 & 8.40 & 7.52 & 7.10 & 5.90 \\
\hline Hati sail (G-20) & 8.1 & 6.7 & 6.3 & 5.7 \\
\hline Black & 5.5 & 4.6 & 4.04 & 3.1 \\
\hline Chini atab & 5.00 & 4.00 & 3.75 & 3.00 \\
\hline Til kapur & 4.6 & 3.8 & 3.5 & 3.05 \\
\hline Chini kamini-2 & 7.10 & 5.95 & 5.20 & 4.50 \\
\hline Rajbhog-2 & 8.9 & 7.83 & 7 & 6.1 \\
\hline Khorina & 8.35 & 8 & 7 & 6.4 \\
\hline Soloi & 8.97 & 7.76 & 7.47 & 5.4 \\
\hline Nonasail & 10.3 & 9.97 & 9.35 & 8.4 \\
\hline Patnai 23 & 11.30 & 10.94 & 10.27 & 9.32 \\
\hline Sada mota & 17.7 & 11.46 & 10.83 & 9.53 \\
\hline Gunshi & 10.1 & 9.27 & 8.56 & 8.1 \\
\hline Koijuri & 9 & 8.99 & 8.33 & 7.15 \\
\hline Chapali & 10.1 & 9.11 & 8.55 & 7.12 \\
\hline IR-29 (check) & 9.7 & 7.8 & 6.8 & 5.6 \\
\hline Pokkali (check) & 10.4 & 9.58 & 9.16 & 8.1 \\
\hline
\end{tabular}

Table 7. Relative dry weight (\%) of different rice genotypes under varied salinity levels

\begin{tabular}{l|c|ccc}
\hline \multirow{2}{*}{ Genotypes } & \multicolumn{4}{|c}{ Relative Dry Weight $(\%)$} \\
\cline { 2 - 3 } & Control & \multicolumn{1}{c}{10} & 15 & 20 \\
\cline { 3 - 3 } Awned-1 & - & 89.52 & 84.52 & 70.24 \\
Hati sail (G-20) & - & 82.72 & 77.78 & 70.37 \\
Black & - & 83.64 & 73.45 & 56.36 \\
Chini atab & - & 80.00 & 75.00 & 60.00 \\
Til kapur & - & 82.61 & 76.09 & 66.3 \\
Chini kamini-2 & - & 83.80 & 73.23 & 63.38 \\
Rajbhog-2 & - & 87.98 & 78.65 & 68.45 \\
Khorina & - & 95.81 & 83.83 & 76.65 \\
Soloi & - & 86.51 & 83.28 & 60.2 \\
Nonasail & - & 96.8 & 90.78 & 81.55
\end{tabular}




Patnai 23
Sada mota
Gunshi
Koijuri
Chapali
IR-29 (check)
Pokkali (check)

\section{Conclusions}

Based on visual salt injury symptoms, 13 genotypes were found tolerant at $15 \mathrm{dSm}^{-1}$ salinity level. However, among the 13 genotypes, only Patnai23 showed higher germination index and seedling relative dry weight than the check salt tolerant Pokkali at 15 $\mathrm{dSm}^{-1}$. Beside these, performance of Awned-1, Nonasail and Soloi were also well at $15 \mathrm{dSm}^{-1}$ salinity level. So, the results of the experiments clearly indicated that most of the rice genotypes could not perform better under salinity level of $15 \mathrm{dSm}^{-1}$ at germination and early seedling stage.

\section{Reference}

Afroze, J. 1996. Cultivar differences in germination, vigor and quality of rice seeds. M. S. Thesis. Institute of Postgraduate Studies in Agriculture, Bangladesh.

Akbar, M., Shakor, A. and Sajjad, M. S. 1997. Prospects of breeding for salt tolerance in rice. In: Genitic Diversity in Plants. (Eds). A. Muhammed, R. Aksel, and R. C. Von Borstel, Basic Life Science, 8: 291-299.

Akbar, M. and Yabuno, T. 1975. Breeding for saline resistant varieties of rice. Ii. Comparative performance of some rice varieties to salinity during early development stages. Japanese Journal of Breeding, 25: 176-181.

Amin, M., Hamid, A., Islam, M. T. and Karim, M. A.1996. Root and shoot growth of rice cultivars in response to salinity. Bangladesh Agronomy Journal, 6(1\&2):41-46.

$\begin{array}{lll}96.81 & 90.88 & 82.48 \\ 90.24 & 85.28 & 75.04 \\ 91.78 & 84.75 & 80.2 \\ 90.81 & 84.14 & 72.22 \\ 90.2 & 84.65 & 70.5 \\ 80.41 & 70.1 & 57.73 \\ 92.12 & 88.08 & 77.88\end{array}$

Asana, R. D. and Kale, V. R. 1965. A study on salt tolerance of four wheat varieties. Indian Journal of Plant Physiology, 8:5-22.

Ayers, A. D. 1953. Germination and emergence of several varieties of barley in salinized soil cultures, Agronomy Journal, 45: 68-71.

Banik, M., Karim, N. H. and Haque, M. Z.1994. Salinity tolerance of rice as related to growth and physiological characteristics. Annals of Bangladesh Agriculture, 4 (1): 41-46

Bewley, J. D. and Black, N. 1982. Physiology and bio-chemistry of seeds in relation to germination. Springer-Verlag, Berlin.

BRRI (Bangladesh Rice Research Institute), 1995. Proceedings of the workshop on coastal salinity and crop production in Bangladesh.

Gregorio, G. B., Senadhira, D. and Mendoza, R. D. 1997. Screening rice for salinity tolerance. IRRI Discussion Paper Series No. 22. IRRI, Philippines. 1-28 pp.

Hossain, M. S. 2004. Effect of salinity on germination, growth, biochemical attributes and yield of rice mutents. $M . S$. Thesis. Bangladesh Agricultural University, Mymensingh.

Islam, M. Z, Baset Mia, M. A., Akter, A. and Rahman, M. H. 2007. Biochemical attributes of mutant rice under different saline levels. International Journal of Sustainable Crop Production. 2(3): 17-21 
Karim, M. A., Utsunomiya, N. and Shigenaga, S. 1992. Effect of sodium chloride on germination and growth of hexaploid triticale at early seedling stage. Japanese Journal of Crop Science. 61: 279-284.

Khan, M. S. A., Hamid, A. and Karim, M. A. 1997. Effect of Sodium Chloride on germination and seedling characters of different types of rice (Oryza sativa L.). Journal of Agronomy and Crop Science. 179: 163-169.

Koyro, H. W. and Eisa, S. S. 2008. Effect of salinity on composition, viability and germination of seeds of Chenopodium quinoa Willd. Plant and Soil. 302(1-2):7990.

Kumar, S., and Bhardwaj, P. 1981. Studies on the genotypic differences in the early seedling growth of various crop plants under saline conditions 1. Mung (Vigna radiate Wilczeck). Indian Journal of Plant Physiology. 24:123-127.

Maliwal, G. L. and Paliwal, K.V. 1967. Salt tolerance studies on some varieties of wheat and barley at germination stage. Indian Journal of Plant Physiology.10:2635.

Mohammad, R. M., Campbell, W. F. and Rumbaugh, M. D. 1989. Variation in salt tolerance of alfalfa. Arid Soil Research. 3: 11-20.

Mondal, T. K., Bal, A. R. and Dal, S. 1988. Effect of salinity on germination and seedling growth of different rice (Oryza sativa L.) cultivars. Journal of the Indian
Society of Coastal Agricultural Research, 6: 91-97.

Pushpam, R. and Rangasamy, S. R. S. 2002. In vivo response of rice cultivars to salt stress. Journal of Ecobiology. 14(3):177182.

Quayyum, H. A., Panaullah, G. M. and Haque, M. Z. 1991. A comparative study of osmotic and ionic effects of salinity on two rice varieties Pokkali and MI48. Bangladesh Journal of Botany, 20(2): 137-142.

Reddy, P. J. and Vaidyanath, K. 1982. Note on the salt tolerance of some rice varieties of Andra Pradesh during germination and early seedling growth. Indian Journal of Agricultural Sciences, 52: 472-474.

Roy, S. K., Patra, S. K. and Sarkar, K. K. 2002. Studies on the effect of salinity stress on rice (Oryza sativa L.) at seedling stage. Journal of Interacademicia, 6(3):254-259.

Russel, D. F. 1986. MSTAT-C, Crop and Soil Sci., Dept, Mitchigan State Univ., USA.

Yeo, A. R., Lee, K. S., Izard, P. Boursier, P. J. and Flowers, T. J. 1991. Short-and long term effects of salinity on leaf growth in rice (Oryza sativa L.). Journal of Experimental Botany, 2: 881-889.

Yoshida, S., 1981. Fundamentals of Rice Crop Science. IRRI, Los Banos, Philippines.

Zeng, L. H. and Shannon, M. C. 2000. Salinity effects on seedling growth and yield components rice. Crop Science, 40 (4): 996-1003. 